\title{
Factors Leading To Success of Indian Construction Companies.
}

\author{
Mr. Abhijeet Gadekar ${ }^{1}$, Dr.S.S.Pimplikar ${ }^{2}$ \\ ${ }^{\text {I}}$ (Student M.E(Construction \& Management), civil engg dept, Maharashtra Institute of Technology, Pune, India) \\ ${ }^{2}$ (Prof \& Head, Civil Engg Dept, Maharashtra Institute of Technology, Pune University, India)
}

\begin{abstract}
Achieving success is a highly critical issue for the companies to survive in a competitive business environment. The construction industry is also an area where there is strong competition due to a large number of construction contractors. There have been many factors such as qualified employees, quality workmanship and financial management that can lead to company success in the construction industry. The aim of this study was to investigate the critical factors leading to construction company success. Within this context, a survey was carried out among 7 Indian construction companies which are located in the Aurangabad district of Maharashtra region of India. In this survey, top-level managers and owners of the companies were interviewed. The interviews took place over a three month period between August and October 2013. Finally, the ranking of the critical success factors has been determined by using the Point Rating Technique. Based on the results, Cash flow management characteristics was determined as the most important factor to company success
\end{abstract}

Keywords : Construction company, Entrepreneurship, Failure factors, Indian construction, Success factors.

\section{INTRODUCTION}

Success has been the ultimate goal of every business activity [1]. It is highly important for the organizations to be successful in their businesses in order to survive in competitive business environments such as construction. The construction industry is changing constantly with the developments of new business methods and technologies [2]. Thus, construction companies have to adopt these applications and develop appropriate strategies to be more competitive in this industry and get success in their businesses. There are many definitions of success. Traditionally, it is defined as the degree to which goals and expectations are met. On the other hand, one of the definitions of failure is the inability of a firm to pay its obligations when they are due [3]. In recent years, there has been an increase in the studies of critical success/failure factors especially in project management subject [4]. The traditional approach to success in the construction industry is to focus on the ability to plan and execute projects [5]. Traditionally, the success parameters for projects in this industry are cost, time and quality [6] However, due to the changing business environment it is crucial to focus on corporate success in order to be competitive in this environment. Some of the researches related to success factors showed that the most important factors contributing to success are company's management systems and practices [7], [8]. Implementation of accounting systems and regular review of financial statements [9], control of job-site safety [10], and ongoing training and education [11] are some other factors contributing to construction company success addressed in the literature. In the study of Hutchings and Christofferson [12], carried out among small-volume residential construction companies in the United States, the most important factors to company success were found as quality workmanship, honesty, having good subcontractors, customer communications, reputation, having good employees, and completing projects on time, respectively. In a survey carried out among Germany's largest construction companies, the most important success factors were identified as employee development, effective risk management, innovation, partnerships with customers, and lean organizational structure [13]. As construction is a risky business and the possibility of business failure always exists, companies have to consider the parameters that can have a direct effect to their success in business. In this study, the critical factors leading to construction company success have been investigated. Within this context, a survey was carried out among 7 Indian construction companies which are located in the Aurangabad district of Maharashtra region of India. Point Rating Scale method is used to determine the ranking of the critical success factors.

\section{INDIAN CONSTRUCTION INDUSTRY}

The construction industry is one of the major industries in India. The Construction industry of India is an important indicator of the development as it creates investment opportunities across various related sectors. The construction industry has contributed an estimated $\mathbf{\mathbf { 2 }} 670,778$ crore to the national GDP in 2011-12 (a share of around $8 \%$ ). The industry is fragmented, with a handful of major companies involved in the construction activities across all segments; medium sized companies specializing in niche activities; and small and medium contractors who work on the subcontractor basis and carry out the work in the field. In 2011, there were slightly over 500 construction equipment manufacturing companies in all of India. The sector is labor-intensive and, 
including indirect jobs, provides employment to more than 35 million people. They are using the most advanced technologies in the market and are able to design, erect, build and operate almost all kinds of civil and industrial projects. Indian contracting services can be divided into two parts as lower-quality domestic-only set of firms and the higher quality international firms. India will become the world's third largest construction market by 2025 , adding 11.5 million homes a year to become a $\$ 1$ trillion a year market, finds a new study by Global construction perspectives and Oxford Economics. India's infrastructure market is expected to grow at around 8 $\%$, the fastest amongst its sector.

The Indian construction industry comprises of numerous firms in the corporate sector. In addition to these firms, there are about 1,20,000 class A contractors registered with various government construction bodies. There are thousands of small contractors, which compete for small jobs or work as sub-contractors of prime or other contractors.

\section{SURVEY}

The aim of this research is to find out the critical factors leading to construction company success. The survey was carried out among 7 Indian construction companies which are located in the Aurangabad district of Maharashtra region of India and operate in the local market. Construction firms registered with the Confederation of Real Estate Developers' Associations of India (CREDAI) at this region were considered in the study. All of these firms are operating in building and housing sectors. In this survey, semi-structured interviews were carried out among top-level managers and owners of the companies. Top-level managers and owners were selected for the interviews because they are assumed to have enough knowledge about the organizational structure, culture and strategies. The 7 interviews took place over a 3 month period between August and October 2013 and each lasted approximately $1 \mathrm{hr}$.

The survey questionnaire was administered during face-to-face interviews and it consisted of 23 questions including both closed and open-ended questions. It is divided into two main sections. Section I covered general information about the companies. Section II dealt with factors leading to company success. Although survey results reflect the opinions of experts from 7 firms, it is believed that they can give an idea about the critical success factors leading to company success in the Indian construction industry. Point Rating Scale method is used to determine the ranking of the critical success factors. The decision maker is asked to rate each of the attributes out of 10 .. The factors considered in the study were identified based on a literature review. A total of possible factors that were felt to have an effect on the construction business success of companies in India were determined. The factors were rated according to their importance and an average ranking of factors was calculated according to the responses.

\section{SURVEY RESULTS}

The respondents were asked to evaluate the importance level of the factors. Table below shows the ranking of the factors according to their importance as perceived by the respondents. Cash flow management was considered as the most important factor to company success. Surprisingly, project management techniques usage was not considered as an important factor for company success. Although the majority of the respondents considered the advanced project management techniques as important tools, it was not seen as a highly essential parameter for company success. The following are the ranking and average rating of the factors that were calculated after obtaining the data from 7 construction companies. 
Table : Ranking \& Average Rating of Factors

\begin{tabular}{|c|c|c|c|}
\hline Ranking & Factors & \multicolumn{2}{|c|}{ Scale Rating } \\
\hline 1 & Cash flow management & 10 & 9.12 \\
\hline 2 & Inadequate sales & 10 & 9 \\
\hline 3 & Lack of managerial experience & 10 & 8.75 \\
\hline 4 & Industry weakness & 10 & 8.5 \\
\hline 4 & Insufficient capital & 10 & 8.5 \\
\hline 4 & Fluctuation in material cost & 10 & 8.5 \\
\hline 4 & Lack of business knowledge & 10 & 8.5 \\
\hline 5 & Poor accounting system & 10 & 7.75 \\
\hline 6 & Heavy operating expenses & 10 & 7.5 \\
\hline 6 & Use of documentation system & 10 & 7.5 \\
\hline 6 & Over expansion & 10 & 7.5 \\
\hline 7 & Insufficient profit & 10 & 7.37 \\
\hline 7 & Estimating practices & 10 & 7.37 \\
\hline 7 & High employee turnover & 10 & 7.37 \\
\hline 8 & Bank policy & 10 & 7.25 \\
\hline 9 & Lack of experience in line of work & 10 & 6.75 \\
\hline 9 & Use of project management techniques & 10 & 6.75 \\
\hline 9 & General economic conditions & 10 & 6.75 \\
\hline 9 & Government policy & 10 & 6.75 \\
\hline 9 & Obtaining work in new region & 10 & 6.75 \\
\hline 10 & Organization structure & 10 & 5.62 \\
\hline 11 & Owner involvement in construction phase & 10 & 5.5 \\
\hline 11 & Lack of early warning measures & 10 & 5.5 \\
\hline
\end{tabular}

\section{CONCLUSION}

This study presented the survey carried out among Indian construction companies. The critical factors leading to construction company success have been investigated through interviews among top-level managers and owners of the companies. According to the results cash flow management characteristic was identified as the most important main factors to success..

Organizing and planning was perceived to be the most important item contributing to company success when considering the importance of the factors. According to the literature review, this result might be expected since planning was addressed as one of the most important items of all the management practices. Moreover, it was interesting to note that managers/owners did not consider project management technique usage as a highly essential item for company success.

The findings in the study should be interpreted with caution since the research was limited with only 7 medium sized firms. Future researches involving managers/owners of top construction companies can provide a comparison of the results of studies conducted in same or other region.

\section{REFERENCES}

[1] A. P. C. Chan, D. Scott, and E. W. M. Lam, "Framework of success criteria for design/build projects", Journal of Management in Engineering, 18(3), 120-128, 2002.

[2] J. Koota, "Market review and study of success characteristics in construction companies - Case: United States', VTT Research Notes 2195, ESPOO 2003.

[3] R. A. I. Frederikslust, “'Predictability of Corporate Failure', Martinus Nijhoff Social Sciences Division,Leiden, The Netherlands, 1978.

[4] I. Hyvari, "Success of projects in different organizational conditions", Project Management Journal, 37(4), 31-41, 2006.

[5] G. L. Abraham, "Critical success factors for the construction industry", In: Moleenar, K R and Chinowsky, P S (Ed.), Proceedings of Construction Research Congress, March 19-21, Honolulu, Hawaii, 2003.

[6] S. W. Hughes, D. D. Tippett, and W. K. Thomas, “Measuring project success in the construction industry", Engineering Manage ment Journal, 16(3), 31-37, 2004

[7] R. N. Lussier, “A nonfinancial business success versus failure prediction model for young firms”, Journal of Small Business Management, January, 8-20, 1995.

[8] D. Strischek, "Red warning flags of contractor failure', Journal of Lending \& Credit Risk Management, 80(11), 40-47, 1998.

[9] D. Gerstel, “'The Builder's Guide to Running a Successful Construction Company”, Newton, CT: The Taunton Press, 1991.

[10] M. Gordon, "Safety saves money”, Contract Journal, 19(3), 1997.

[11] T. F. Bednarz, "Winning strategy: the nine laws of business success", Air Conditioning, Heating \& Refrigeration News, 32-33, 1997.

[12] M. Hutchings, and J. Christofferson, "Factors leading to construction company success: perceptions of small-volume residential contractors", ASC Proceedings of the 37th Annual Conference, University of Denver, Colorado, 263-270, 2001.

[13] Roland Berger Strategy Consultants, "Success factors in the construction industry in 2004", Industry radar - findings of the trend survey, Munich, June 2004. 